\title{
Alus dzērienu sensorais novērtējums Sensory Evaluation of Beer Drinks
}

\author{
Ingmars Cinkmanis ${ }^{1 *}$, Evita Straumite ${ }^{2}$, Ilze Cakste ${ }^{1}$ \\ ${ }^{1}$ LLU Ķīmijas katedra \\ ${ }^{1}$ Department of Chemistry, LLU, Liela iela 2, Jelgava LV-3001, Latvia \\ ${ }^{2}$ LLU Pārtikas tehnoloǵijas katedra \\ ${ }^{2}$ Department of Food Technology, LLU, Liela iela 2, Jelgava LV-3001, Latvia
}

\begin{abstract}
In brewing, the raw materials that give the beer its specific colour, taste, and aroma are hop, barley malt, yeast, and water. However, these traditional raw materials can be partially or completely replaced with other products. A possibility of replacing hops with parts of plants (oak bark or acorn, yarrow, and wormwood) rich in bitter substances was researched. During the wort boiling process, hops were replaced with $0.2 \mathrm{~g} \mathrm{~L}^{-1}$ of oak bark, or acorn, or yarrow, or wormwood. As a result, the four beer drinks produced were analysed for the degree of liking and the intensity of sensory properties (turbidity, aroma, malt aroma, brown colour, and astringency) according to ISO 4121:2003. All beer drinks were designated by uppercase letters: A - beer drink with yarrow; B - with oak bark; C - with oak acorn; and D - with wormwood. A total of 25 assessors (18 women and 8 men), with the average age of 35 years, participated in the sensory evaluation of beer drinks. No significant differences in the degree of liking $(p>0.05)$ were established among beer drinks with yarrow, with oak bark or acorn. The added hop substitutes had a significant effect $(p<0.05)$ on the intensity of turbidity, malt aroma, bitterness, and astringency of the four beer drinks. According to the assessors' evaluation, the wormwood beer drink had an overly strong, bitter taste. Therefore, a conclusion was drawn that the concentration of wormwood should be reduced in the wort during its boiling process.
\end{abstract}

Key words: Sensory evaluation, beer drinks, hop substitute.

\section{Ievads}

Pēdējo gadu laikā palielinās dažādu netradicionālu alus dzērienu piedāvājums. Piemēram, Latvijā a/s „Aldaris” ražotu alus kokteiļu sērija DLight, a/s „Cēsu alus” Beershake, SIA „Ilgezeem” kviešu, dzērveņu un medus alus, kā arī SIA „Brūveris” IngverAlus un Ķiršu IngverAlus. Līdz ar to esošais tradicionālais alus klāsts tiek paplašināts ar netradicionāliem alus dzērieniem, kas atšķiras ar savu garšu, smaržu, izskatu un sastāvu.

Netradicionāli iegūto alus dzērienu piedāvājums ir plašs, jo ražošanas procesā jebkuru no tradicionāli izmantotajām alus izejvielām apiņus, miežus, raugu un ūdeni - daḷēji vai piln̄̄gi iespējams aizvietot ar netradicionālām izejvielām. Tāpēc pêtījumā izvēlējāmies apiņu vietā pievienot rūgtvielām bagātu augu piedevas - pelašķus, vērmeles, ozolu mizas un zīles.
Izveidojot jaunus alus dzērienus, vispusīgi jāizvērtē to kvalitāte, t.sk. sensorās īpašības, jo, mijiedarbojoties dažādam izejvielām, ražošanas procesā notiek bioķīmiskas pārvērtības, kuru rezultātā veidojas vairāki simti dažādu vielu, kas piedalās alus garšas un aromāta veidošanā un kas var ietekmēt - pozitīvi vai negatīvi - vēlamo rezultātu. Šo vielu daudzveidība, koncentrācija un savstarpējā mijiedarbība nosaka alus dzēriena sensorās īpašības.

Misas iegūšanas laikā notiek procesi, kuru rezultātā produktam veidojas aromāts, garša un krāsa (no gaiši dzeltenas līdz tumši brūnai), piemēram, Mailarda reakcijā no glikozes un $\alpha$-aminoskābēm vai amīniem, kā arī termiski vai enzimātiski sadaloties lip̄̄diem (Coghe, Derdelinckx, \& Delvaux, 2004). Pārvērtību rezultātā veidojas dažādas ķīmiskās vielas: melanoīdi, taukskābes, aldehīdi, spirti, furāni,

\footnotetext{
* Corresponding author's email:

Ingmars.Cinkmanis@llu.lv
} 
ketoni, fenoli, pirazīni un sēra savienojumi (Herent, Vanthournhout, Gijs, \& Collin, 1997). Iesala sensorās īpašības būtiski ietekmē furaneols, maltols un izomaltols (Hughes \& Baxter, 2001).

Misas rūgšanas procesā veidojas tikai alus dzērieniem raksturīgā garša un aromāts. Dominējošās vielas, kas rodas rūgšanas procesā, ir etanols un oglekḷa dioksīds. Bez tām veidojas arī esteri, garo virkṇu spirti, aldehīdi, diacetils un sēra savienojumi (Boulton \& Quain, 2006; Casey, 2007; Hughes \& Baxter, 2001).

Alus produktu vēlamo vai nevēlamo krāsu, aromātu un garšu veidojošo vielu koncentrācijas ir ļoti mazas - no dažiem mikrogramiem $(\mu \mathrm{g})$ līdz miligramiem (mg). Sensoro īpašǐbu vērtēšanai Meilgards (Meilgaard, 1975) 1975. gadā izveidoja kopēju mērvienību - aromāta vienību (flavor unit - FU). Saskan̄ā ar Meilgarda ierosināto aprēķinu formulu, ja vielas koncentrācija pārsniedz $1 \mathrm{FU}$, tad alus sensorās īpašības pasliktinās.

Cilvēku garšas uztveršanas slieksnis spēj noteikt l’oti zemās koncentrācijās apmēram 600 700 vielu, kas pārstāv tādas organisko vielu klases kā aldehīdi, ketoni, cikliskie acetāli, heterocikliskie savienojumi, etilesteri, laktoni un sēra savienojumi (Bamforth, 2000; Hashimoto, 1972a, b). Vairāku zinātnieku pētījumi ir pierādījuši, ka alus bojāšanos uzglabāšanas procesā var konstatēt, nosakot tajā tikai vienu kīimisku savienojumu - E-non-2-ēnālu (Foster, Samp, \& Patino, 2001; Narziss, Miedaner, \& Lustig, 1999; Schieberle \& Komarek, 2002; Van Eerde \& Strating, 1981; Vesely, Lusk, Basarova, Seabrooks, \& Ryder, 2003).

Sensorās īpašǐbas negatīvi var ietekmēt alū notiekošie ķ̄miskie procesi: vicinālo diketonu veidošanās (Inoue \& Yamamoto, 1971), dažādu sēra savienojumu veidošanās (Bamforth, 1985; Gijs, Chevance, Jerkovic, \& Collin, 2002; Walker \& Simpson, 1994), esteru koncentrācijas palielināšanās (Gijs, Chevance, Jerkovic, \& Collin, 2002), garo virkṇu spirtu oksidēšanās produkti (Devreux, Blockmans, \& Van de Meerrsche, 1981; Irwin, Barker, \& Pipasts, 1991), nepiesātināto taukskābju enzimātiskā un neenzimātiskā oksidēšanās (Bamforth, 1999; Bamforth, Clarkson, \& Large, 1991; Bamforth, Muller, \& Walker, 1993; Doderer et al., 1992; Hirota et al., 2005; Kaneda, Takashio, Tomaki, \& Osawa, 1997; Kuroda, Furusho, Maeba, \& Takashio, 2003; Lermusieau, Noël, Liégeois, \& Collin, 1999) un citas pārvērtības.
Mūsu pētījumā tradicionālajā alus darī̌anā izmantotie apini tika aizstāti ar rūgtvielām bagātu augu piedevām - pelašķiem, vērmelēm, ozolu mizām un zîlēm -, tādēḷ bija vispusīgi jāizvērtē jauniegūto alus dzērienu kvalitāte, t.sk. sensorās īpašības. Sensorais novērtējums ir viens no visizplatītākajiem, vienkāršākajiem un ātrākajiem analīzes veidiem, kas l̦auj noteikt būtiskus produkta kvalitātes rādītājus, izmantojot cilvēka maņu orgānus. Apkopojot iepriekš minēto, pētījuma mērķis bija analizēt alus dzērienu patikšanas pakāpi un sensoro īpašǐbu intensitāti.

\section{Materiāli un metodes Alus dzērienu ražošanas izejvielas}

Kaltètas Latvijā audzētas augu dą̧as: ozolu mizas, ozolu zīles, pelašķi (Achillea millefolium L.) un vērmeles (Artemisia absinthium L.). Augu izejvielas ievāca un žāvēja saskaņā ar norādēm (Rubine \& Eniņa, 2004). Gaišais miežu iesals („Brupaks”, Anglija), alus raugs (Saccharomyces pastorianus) („Lallemand”, Kanāda), dzeramais ūdens (SIA „Grigis un Co”) (LR Ministru ..., 2003).

\section{Alus dzērienu gatavošana}

Vispārīga alus dzērienu ražošanas tehnoloǵiskā shēma parādìta 1. attēlā. Eksperimentos paskābināšanai tika izmantota cidoniju sula un misas vārišanā tradicionāli izmantotās izejvielas tika mainītas, apiņu vietā pievienojot rūgtvielām bagātas augu daḷas $\left(0.2 \mathrm{~g} \mathrm{~L}^{-1}\right)$ : žāvētas ozolu mizas, zīles, pelašķus un vērmeles (Cinkmanis, Čakste, \& Vucāne, 2013).

\section{Sensorā novērtēšana}

Alus dzērienu patikšanas pakāpes noteikšanai izmantota 9 punktu hēdoniskā skala $(1$ - ārkārtīgi nepatîk; 2 - l̦oti nepatîk; 3 - vidēji nepatīk; 4 mazliet nepatīk; 5 - ne patīk, ne nepatîk; 6 - mazliet patîk; 7 - vidēji patīk; 8 - loti patîk; 9 - ārkārtīgi patîk), un dzērienu sensoro īpašību (dzidrība, aromāts, iesala aromāts, brūnā krāsa, rūgtā un savelkošā garša) intensitāte noteikta, izmantojot līnijskalas metodi (ISO 4121:2003). Alus dzērienu sensorajā novērtēšanā piedalījāās 25 apmācīti vērtētāji (18 sievietes, 8 vīrieši), kuru vidējais vecums bija 35 gadi. Pētījumā izmantoti šãdi alus dzērienu šifri: A - ar pelašķiem, B - ar ozolu mizām, C - ar ozolu zīlēm, un D - ar vērmelēm. Sensorās analīzes laikā katrs eksperts sañēma četru alus dzērienu paraugus (katrs paraugs $30 \mathrm{~mL}$ ), kuru temperatūra bija $+4{ }^{\circ} \mathrm{C}$. 


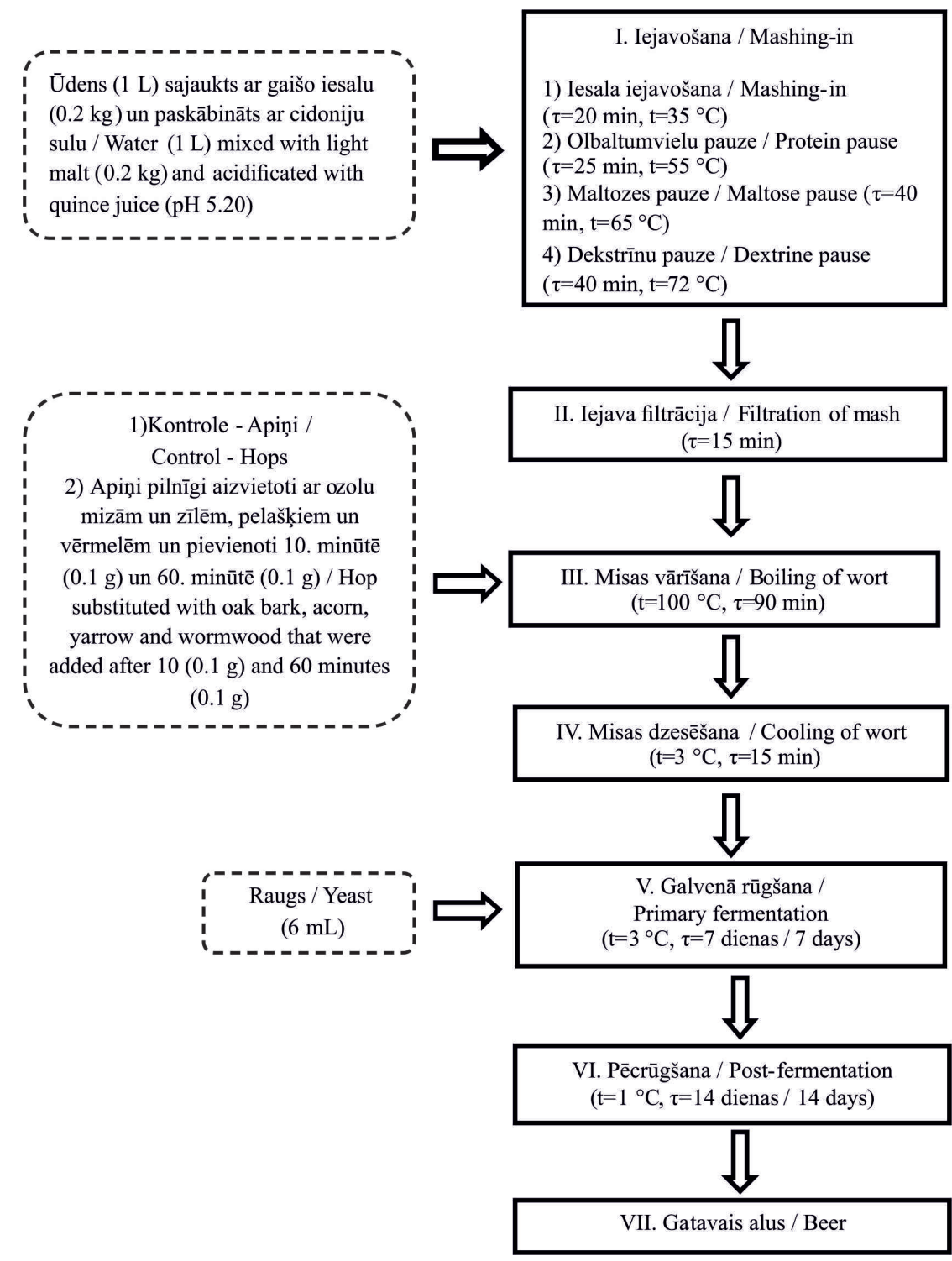

1. att. Alus dzērienu ražošanas tehnolog̣iskā shēma.

Fig. 1. Technological scheme for production of beer drinks.

\section{Datu matemātiskā apstrāde}

Lai izvērtētu alus dzērienu sensorajā novērtēšanā iegūtos datus, tika lietota dispersijas analīze (ANOVA), Tjūkija tests un korelācijas analīze.

\section{Rezultāti un diskusija}

Lai novērtētu alus dzērienu ar pelašksiem (A paraugs), ar ozolu mizām (B paraugs), ar ozolu zīlēm (C paraugs) un ar vērmelēm (D paraugs) patikšanas pakāpi, izmantota 9 punktu hēdoniskā skala un iegūtie rezultāti apkopoti 2. attēlā.

Hēdoniskās vērtēšanas rezultātā varēja secināt, ka apmācītajiem vērtētājiem vienlīdz labi patika paraugi $\mathrm{A}, \mathrm{B}$ un $\mathrm{C}$, turklāt starp tiem patikšanas ziṇā nepastāvēja būtiska atšķirīiba $(p>0.05)$. Patikšanas ziņā būtiski atšķirīgs $(p<0.05)$ bija alus dzēriens ar vērmelēm (D paraugs). Vērtētāji to raksturoja kā lıtoti rūgtu, ar izteiktu vērmel̦u garšu, kas ir neraksturīga tradicionālajam alum.

Alus dzērienu patikšanas pakāpe bija robežās no 4.12 (mazliet nepatîk) līdz 6.19 (mazliet patīk).

Alus dzērienu sensoro īpašību intensitātes noteikšanai izmantota līnijskala, un iegūtie rezultāti apkopoti 1. tabulā un 3. attēlā.

Statistiski izvērtējot iegūtos datus, var secināt, ka būtiskas atšķirības $(p>0.05)$ starp alus dzērienu aromātiem nepastāvēja. Līdz ar to var teikt, ka pievienotās augu daḷas neietekmēja alus aromātu veidojošo vielu saturu, kas bija radies 


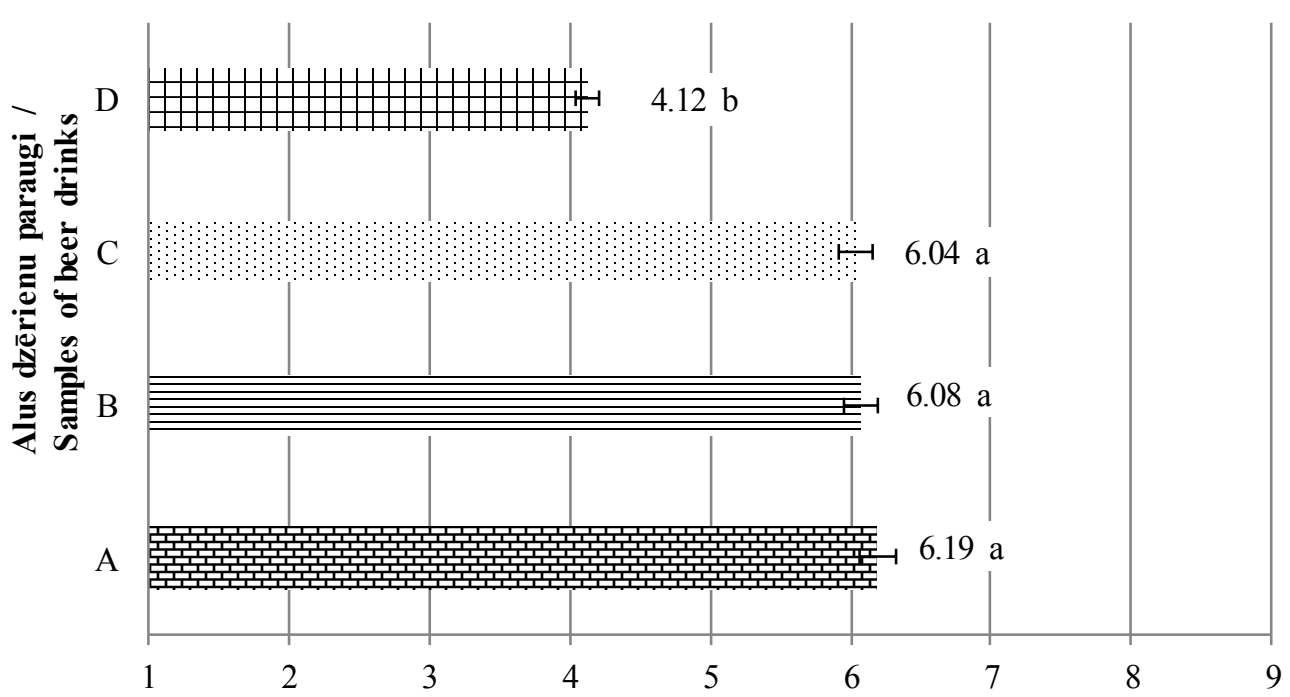

Hēdoniskās skalas vērtības / Values of hedonic scale

A - pelašķu, B - ozolu mizu, C - ozolzịlı lu, D - vērmel̦u

A - yarrow, B - oak bark, C - acorn, D - wormwood

Piezīme. Paraugi, kuri apzīmēti ar vienu un to pašu burtu, nav būtiski atšķirīgi ( $p>0.05)$.

Note. Samples marked with the same letter have no significant difference $(p>0.05)$.

2. att. Alus dzērienu hēdoniskā novērtējuma rezultāti.

Fig. 2. The results of the overall acceptance of beer drinks.

Alus dzērienu sensoro īpašǐbu intensitāte

1. tabula / Table 1

The intensity of the sensory properties of beer drinks

\begin{tabular}{ccccc}
\hline \multirow{2}{*}{$\begin{array}{c}\text { Sensorās īpašības / } \\
\text { Sensory properties }\end{array}$} & $\begin{array}{c}\text { ar pelašķiem / } \\
\text { with yarrow }\end{array}$ & $\begin{array}{c}\text { ar ozolu mizām / } \\
\text { with oak bark }\end{array}$ & $\begin{array}{c}\text { ar ozolu zīlēm / } \\
\text { with oak acorn }\end{array}$ & $\begin{array}{c}\text { ar vērmelēm / } \\
\text { with wormwood }\end{array}$ \\
\hline Dzidrums / Clarity & $7.52 \mathrm{a}$ & $7.19 \mathrm{a}$ & $5.99 \mathrm{~b}$ & $5.98 \mathrm{~b}$ \\
\hline Aromāts / Aroma & $2.87 \mathrm{a}$ & $3.03 \mathrm{a}$ & $3.11 \mathrm{a}$ & $3.92 \mathrm{a}$ \\
\hline $\begin{array}{c}\text { Iesala aromāts / } \\
\text { Malt aroma }\end{array}$ & $5.24 \mathrm{a}$ & $4.27 \mathrm{ab}$ & $3.88 \mathrm{~b}$ & $3.71 \mathrm{~b}$ \\
\hline $\begin{array}{c}\text { Brūna krāsa / } \\
\text { Brown colour }\end{array}$ & $4.63 \mathrm{a}$ & $4.49 \mathrm{a}$ & $4.73 \mathrm{a}$ & $4.95 \mathrm{a}$ \\
\hline $\begin{array}{c}\text { Rūgta garša / } \\
\text { Bitter taste }\end{array}$ & $2.96 \mathrm{a}$ & $3.90 \mathrm{~b}$ & $2.97 \mathrm{a}$ & $8.84 \mathrm{c}$ \\
\hline $\begin{array}{c}\text { Savelkoša garša / } \\
\text { Astringent taste }\end{array}$ & $2.96 \mathrm{a}$ & $2.98 \mathrm{a}$ & $2.88 \mathrm{a}$ & $5.75 \mathrm{~b}$ \\
\hline
\end{tabular}

Piezīme. Paraugi, kuri apzīmēti ar vienu un to pašu burtu rindā, nav būtiski atšksirīgi $(p>0.05)$.

Note. The samples marked with the same letter in a row have no significant difference $(p>0.05)$.

galvenās rūgšanas laikā rauga metabolisma procesā.

Iegūtais brūnās krāsas intensitātes statistiskais izvērtējums rāda, ka starp alus dzērieniem brūnās krāsas intensitātes zin̄ā nebija būtiska $(p>0.05)$ atšķirība. Brūno krāsu veido dažādi Mailarda reakcijas produkti (mazmolekulāri [LMW] hromofori $(<1 \mathrm{kDa})$ un augstmolekulāri [HMW] melanoidīni [>100 kDa]) (Ames \& Nursten, 1989; Hofmann, 1998), tādēḷ var secināt, ka pievienotās dažādās rūgtvielas saturošās augu daļas neietekmēja iegūto alus dzērienu krāsu. Savukārt izmantotie 


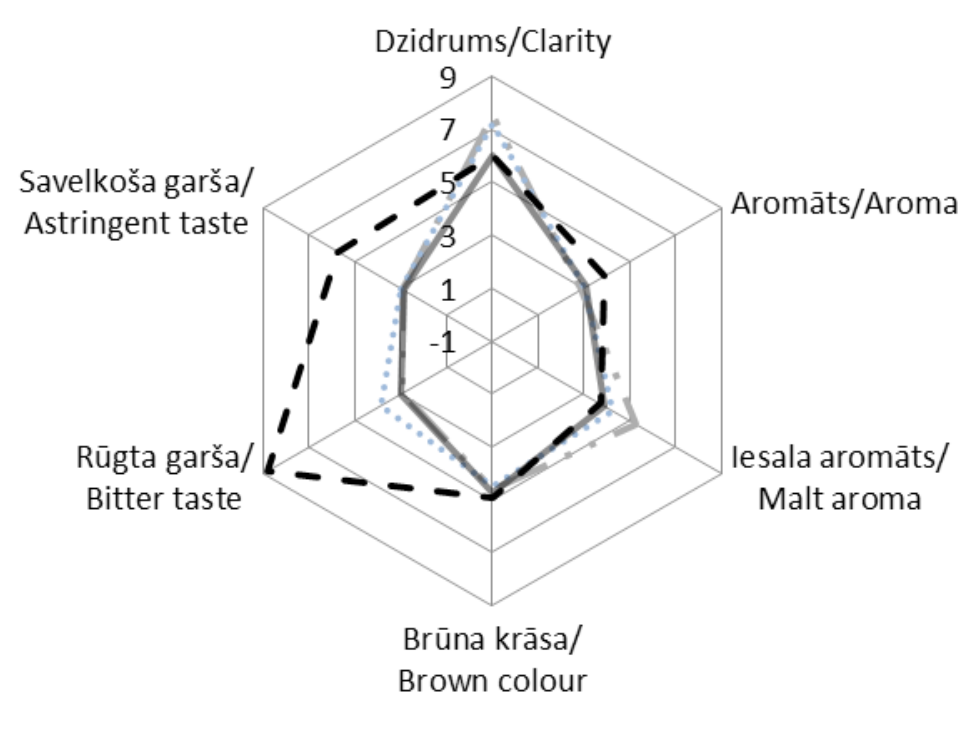

A - pelašķu, B - ozolu mizu, C - ozolzịlu, D - vērmeḷu

A - yarrow, B - oak bark, C - acorn, D - wormwood

3. att. Alus dzērienu sensorā novērtējuma staru diagramma.

Fig. 3. The star diagram of the sensory evaluation of beer drinks.

apiṇu aizvietotāji - pelašksi, ozolu mizas, ozolu zīles un vērmeles - būtiski ietekmēja $(p<0.05)$ alus dzērienu dzidrumu, iesala aromātu un rūgto un savelkošo garšu (1. tabula).

Alus dzērieni ar pelašksiem (A paraugs) un ozolu mizām (B) bija dzidrāki nekā ar ozolu zīlēm (C) un vērmelēm (D), tomēr būtiska $(p>0.05)$ atšķirība starp tiem dzidruma zin̄ā nepastāvēja. Viens no svarīgākajiem faktoriem, lai iegūtu dzidru alus dzērienu, ir iesala un pievienotā auga kopējo polifenolu saturs, jo, kā norāda Kunze (1998), tieši apiņu polifenoli reakcijā ar olbaltumvielām veido sarežğîtus kompleksus savienojumus, kuri spēj ietekmēt gatava alus dzidrumu. Tā kā mūsu petījumā pievienotais iesala daudzums visiem alus dzērieniem bija nemainīgs, tad var pieņemt, ka dzidrumu būtiski ietekmējošie faktori bija augu daļu dažādie polifenoli. Iespējams, misas vārī̌sanas procesā pievienotās ozolu zīles un vērmeles, līdzīgi apiņiem, labāk spēj saistīt un nogulsnēt olbaltumvielu-polifenolu kompleksos savienojumus.

Visintensīvāko iesala aromātu konstatējām alus dzērienam ar pelašķiem (A paraugam), un tas būtiski atšksīrās $(p<0.05)$ no pārējiem alus dzērieniem.

Rūgtās garšas intensitātes ziṇā paraugi A un C (ar pelašķiem un ozolu zīlēm) viens no otra neatšķīīās $(p>0.05)$, taču tie abi būtiski atšks̄īās $(p<0.05)$ no B parauga (ar ozolu mizām). Alus dzērienam ar vērmel̦u piedevu $\left(0.2 \mathrm{~g} \mathrm{~L}^{-1}\right)$ bija izteikti rūgta garša, kas ne visiem vērtētājiem patika. Alus dzērienam ar pelašksu piedevu netika konstatēta rūgta garša, bet alus dzērieniem ar ozolu mizu un zịḷu piedevu bija izteiktāka savelkošā tannīnu garša.

Pievienoto augu daḷu sastāvā ir dažādas rūgtvielas: vērmeles satur seskviterpēna laktonu, kā arī absintīnu (0.20-0.28\%) un artabsīnu (0.04$0.16 \%$ ) (Frohne, 1984); pelašķi satur pirolidīna alkaloīdu ahileīnu (Hänsel \& Hölzl, 1996); ozolu mizas un zīles satur glikozīdu kvercīnu (Thomson, 2012). Kā norāda Stromers (Ströhmer, 2002), absintīns un artabsīns ir vieni no visrūgtākajiem ķīmiskajiem savienojumiem, kurus nelielos daudzumos cilvēki spēj sensori konstatēt, kas arī izskaidro vērmeḷu alus dzēriena izteikti rūgto garšu mūsu pētījumā.

Savelkošā garša visizteiktākā bija alus dzēriena D paraugam (ar vērmelēm), un tā būtiski atšķ̄īās $(p<0.05)$ no A, B un C paraugu savelkošās garšas. Savukārt A (ar pelašķiem), B (ar ozolu mizām) un C (ar ozolu zīlēm) paraugu savelkošās garšas intensitātes būtiski neatšks̄īās $(p>0.05)$. Literatūrā norādīts, ka tieši tannīnu saturs ietekmē vērtētāja savelkošās garšas sajūtu (Lawless \& Heymann, 2010). Pētîjumos vislielākais to saturs konstatēts ozolu mizās un zīlēs (6.7-8.3\%) un pelašķos (3$4 \%$ ), bet vērmelēs tie prakstiski nav sastopami (Bajaj, 1993; Hänsel \& Hölzl, 1996). Līdz ar to 
Alus dzērienu sensoro īpašību savstarpējā korelācija Correlation among the sensory properties of beer drinks

\begin{tabular}{|c|c|c|c|c|c|c|}
\hline & $\begin{array}{c}\text { Dzidrums / } \\
\text { Clarity }\end{array}$ & $\begin{array}{c}\text { Aromāts / } \\
\text { Aroma }\end{array}$ & $\begin{array}{c}\text { Iesala } \\
\text { aromāts / } \\
\text { Malt aroma }\end{array}$ & $\begin{array}{l}\text { Brūna krāsa / } \\
\text { Brown colour }\end{array}$ & $\begin{array}{c}\text { Rūgta garša / } \\
\text { Bitter taste }\end{array}$ & $\begin{array}{l}\text { Savelkoša garša } \\
\text { / Astringent taste }\end{array}$ \\
\hline $\begin{array}{c}\text { Dzidrums / } \\
\text { Clarity }\end{array}$ & 1 & & & & & \\
\hline Aromāts / Aroma & -0.711 & 1 & & & & \\
\hline $\begin{array}{c}\text { Iesala aromāts / } \\
\text { Malt aroma }\end{array}$ & 0.895 & -0.714 & 1 & & & \\
\hline $\begin{array}{l}\text { Brūna krāsa / } \\
\text { Brown colour }\end{array}$ & -0.772 & 0.865 & -0.546 & 1 & & \\
\hline $\begin{array}{l}\text { Rūgta garša / } \\
\text { Bitter taste }\end{array}$ & -0.531 & 0.973 & -0.578 & 0.781 & 1 & \\
\hline $\begin{array}{l}\text { Savelkoša garša / } \\
\text { Astringent taste }\end{array}$ & -0.553 & 0.973 & -0.537 & 0.849 & 0.990 & 1 \\
\hline
\end{tabular}

vērmelēm piešķirtā savelkošā garša mūsu pētîjumā, iespējams, bija saistīta galvenokārt ar tajās esošajiem loti rūgtajiem absintīnu un artabsīnu, kuri negatīvi ietekmēja sensoro vērtētāju spēju sajust vērmeḷu savelkošo garšu.

2. tabulā apkopota informācija par pētīto alus dzērienu (ar pelašķiem, ozolu mizām, ozolu zīlēm un vērmelēm) sensoro īpašību savstarpējo korelāciju. No iegūtajiem datiem var secināt, ka, ja alus dzērienam ir rūgta garša, tad paraugam tiks noteikta arī savelkoša garša $(\mathrm{r}=0.990)$. Tas jāṇem vērā, izstrādājot receptūru alus dzērieniem, jo pārāk izteikta savelkoša garša vērtētājiem (potenciālajiem patērētājiem) nebija pieņemama. Tāpat pastāvēja cieša korelācija $(\mathrm{r}=0.900)$ starp rūgto, savelkošo garšu un aromātu: jo izteiktāka bija alus dzērienu rūgtā vai savelkošā garša, jo izteiktāks bija to aromāts.

\section{Secinājumi}

1. Vērtētājiem vienlīdz labi patika alus dzērieni ar pelašķiem, ar ozolu mizām un ar ozolu zīlēm. Patikšanas zin̄ā starp tiem nepastāvēja būtiska atšksirība $(p>0.05)$, taču alus dzēriens ar vērmelēm bija būtiski atšksirīgs $(p<0.05)$.

2. Dažādo alus dzērienu aromāti un brūnās krāsas intensitātes būtiski $(p>0.05)$ neatšķ̄īrās, tomēr pelašķi, ozolu mizas, ozolu zīles un vērmeles būtiski ietekmēja $(p<0.05)$ alus dzērienu dzidrumu, iesala aromātu un rūgto un savelkošo garšu.
3. Pilnveidojot receptūru vērmel̦u alus dzērienam, jāṇem vērā tā pārāk izteiktā rūgtās garšas intensitāte, tādēḷ misas vārīšanas procesā ieteicams samazināt klāt pievienoto vērmeļu daudzumu.

\section{Literatūra}

1. Ames, J.M., \& Nursten, H.E. (1989). Recent advances in the chemistry of coloured compounds formed during the Maillard reaction. In W.S. Lien \& C.W. Foo (Eds.), Trends in food science (pp. 8-14). Singapore: Singapore Institute of Food Science and Technology.

2. Bajaj, Y.P.S. (Ed.) (1993). Biotechnology in agriculture and forestry, 24. Medicinal and aromatic plants $V$. Berlin: Springer-Verlag.

3. Bamforth, C.W. (1985). Cambridge prize lecture: Biochemical approaches to beer quality. Journal of the Institute of Brewing, 91, 154-160.

4. Bamforth, C.W. (1999). Enzymic and nonenzymic oxidation in the brewhouse: A theoretical consideration. Journal of the Institute of Brewing, 105, 237-242.

5. Bamforth, C.W. (2000). Making sense of flavor change in beer. Master Brewers Association of the Americas Technical Quarterly, 37, 165-171.

6. Bamforth, C.W., Clarkson, S.P., \& Large, P.J. (1991). The relative importance of polyphenol oxidase, lipoxygenase and peroxidases 
during wort oxidation. In Proceedings of the 23rd European Brewery Convention Congress (pp. 617-624). Lisbon, Portugal: USA, Oxford University Press.

7. Bamforth, C.W., Muller, R.E., \& Walker, M.D. (1993). Oxygen and oxygen radicals in malting and brewing. Journal of the American Society of Brewing Chemists, 51, 79-88.

8. Boulton, C., \& Quain, D. (2006). Brewing yeasts and fermentation (pp. 113-141). Oxford: Blackwell.

9. Casey, G.P. (2007). A journey in brewing science and the ASBC. In P.W. Gales (Ed.), Brewing chemistry and technology in the Americas (pp. 99-231). St Paul, MN: P.W. Gales.

10. Cinkmanis, I., Čakste, I., Vucāne, S. (2013). LR Patenta pieteikums Nr. P-13-226. Rīga. Latvijas Republikas Patentu valde.

11. Coghe, S., Derdelinckx, G., \& Delvaux, F.R. (2004). Effect on non-enzymic browning on flavour, colour and antioxidative activity of dark specialty malts - a review. Monatsschrift für Brauwissenschaft, 57, 25-38.

12. Devreux, A., Blockmans, C., \& van de Meerrsche, K. (1981). Carbonyl compounds formation during aging of beer. EBC - Flavor Symposium, Monograph VII (pp. 191- 201). Copenhagen: EBC.

13. Doderer, A., Kokkelink, I., Van der Veen, S., Valk, B.E., Schram, A.W., \& Douma, A.C. (1992). Purification and characterization of two lipoxygenase isoenzymes from germinating barley. Biochimica et Biophysica Acta, 1120, 97-104.

14. Foster, R.T., Samp, E.J., \& Patino, H. (2001). Multivariate modeling of sensory and chemical data to understand staling in light beer. Journal of the American Society of Brewing Chemists, 59, 201-210.

15. Frohne, D. (1984). Wermutkraut. In M. Wichtl (Ed.), Teedrogen (pp. 363- 365). Stuttgart, Germany: Wissenschaftliche Verlagsgesellschaft.

16. Gijs, L., Chevance, F., Jerkovic, V., \& Collin, S. (2002). How low $\mathrm{pH}$ can intensify $\beta$-damascenone and dimethyl trisulfide production through beer aging. J.Agric.Food Chem. 50 (20), 5612-5616. DOI: $10.1021 / \mathrm{jf020563p.}$

17. Hänsel, R., \& Hölzl, J. (1996). Lehrbuch der pharmazeutischen Biologie: Ein Lehrbuch für Studenten der Pharmazie im zweiten Ausbildungsabschnitt. Springer DE.
18. Hashimoto, N. (1972b). Oxidation degradation of isohumulones in relation to beer flavor. Oxidation of higher alcohols by melanoidins in beer. Report of the Research Laboratory of the Kirin Brewery Company, 15, 7-15.

19. Hashimoto, N. (1972a). Oxidation of higher alcohols by melanoidins in beer. Journal of the Institute of Brewing, 78, 43-51.

20. Herent, M.F., Vanthournhout, C., Gijs, L., \& Collin, S. (1997). Influence de la composition en heterocycles azotes de malts speciaux sur le profi le aromatique de la biere. In Proceedings of the 26th EBC Congress (pp. 167-174). Maastricht, the Netherlands.

21. Hirota, N., Kuroda, H., Takoi, K., Kaneko, T., Kaneda, H., Yoshida, I., ... Takeda, K. (2005). Development of novel barley with improved beer foam and flavor stability - the impact of lipoxygenase-1-less barley in brewing industry. In Proceedings of the 30th European Brewery Convention Congress (pp. 46-52). Prague, Czech Republic.

22. Hofmann, T. (1998). Studies on melanoidin-type colourants generated from the Maillard reaction of casein and furan-2-carboaldehyde - chemical characterisation of a red coloured domain. Z. Lebensm. Unters. Forsch., 206, 251-258.

23. Hughes, P.S., \& Baxter, E.D. (2001). Beer: Quality, safety and nutritional aspects. Cambridge: Royal Society of Chemistry.

24. Inoue, T., \& Yamamoto, Y. (1971). Decomposition rate of precursors of diacetyl and 2,3-pentanedione during beer fermentation. Report of the Research Laboratory of the Kirin Brewery Company, 14, 55-59.

25. Irwin, A.J., Barker, R.L., \& Pipasts, P. (1991). The role of copper, oxygen and polyphenols in beer flavor instability. Journal of the American Society of Brewing Chemists, 49, 140-149.

26. ISO 4121:2003. Sensory analysis - Guidelines for the use of quantitative response scales. Retrieved from http://www.iso.org/iso/home/ store/catalogue_ics/catalogue_detail_ics.htm?ic $\mathrm{s} 1=67 \& \mathrm{ics} 2=240 \& \mathrm{ics} 3=$ \&csnumber $=33817$

27. Kaneda, H., Takashio, M., Tomaki, T., \& Osawa, T. (1997). Influence of $\mathrm{pH}$ on flavor staling during beer storage. Journal of the Institute of Brewing, 103, 21-23.

28. Kunze, W. (1998). Technology of malting and brewing, Berlin: VLB.

29. Kuroda, H., Furusho, S., Maeba, H., \& Takashio, M. (2003). Characterization of factors 
involved in the production of E-(2)-nonenal during mashing. Bioscience Biotechnology and Biochemistry, 67, 691-697.

30. Lawless, H.T., \& Heymann, H. (2010). Sensory evaluation of food: Principles and practices (2nd ed.). New York: Springer.

31. Lermusieau, G., Noël, S., Liégeois, C., \& Collin, S. (1999). Nonoxidative mechanism for development of trans-2-nonenal in beer. Journal of the American Society of Brewing Chemists, 57, 29-33.

32. LR Ministru kabinets. (2003). Dzeramā ūdens obligātās nekaitīguma un kvalitātes prasības, monitoringa un kontroles kārtība. MK noteikumi Nr. 235, 2003. g. 29. aprīlī. Retrieved from http://likumi.lv/doc.php?id= 75442

33. Meilgaard, M.C. (1975). Flavour chemistry of beer - Part I: Flavour interactions between principal volatiles. Master Brewers Association of the Americas Technical Quarterly, 12, 107-117.

34. Narziss, L., Miedaner, H., \& Lustig, S. (1999). The behavior of volatile aromatic substances as beer ages. Monatsschrift für Brauwissenschaft, 52, 164-175.

35. Rubine, H., \& Eniņa, V. (2004). Arrstniecības augi. Rīga: Zvaigzne ABC.
36. Schieberle, P., \& Komarek, D. (2002). Changes in key aroma compounds during natural beer aging. In K.R. Cadwallader \& H. Weenen (Eds.), Freshness and shelf life of foods (pp. 70-79). ACS: Washington, DC.

37. Ströhmer, G. (2002). Rohstoffe und Halbfabrikate zur Herstellung von Likören. In E. Kolb (Ed.), Spirituosen-Technologie (pp. 161-343). Hamburg, Germany: Behr's Verlag,

38. Thomson, R.D. (2012). Dictionary of Chemistry, With Its Applications to Mineralogy, Physiology, and the Arts. HardPress Publishing.

39. Van Eerde, P., \& Strating, J. (1981). Trans2-nonenal. EBC - Flavor Symposium, Monograph VII (pp. 117-121). Copenhagen: EBC.

40. Vesely, P., Lusk, L., Basarova, H., Seabrooks, J., \& Ryder, D. (2003). Analysis of aldehydes in beer using solid-phase microextraction with on-fiber derivatization and gas chromatography/mass spectrometry. Journal of Agricultural and Food Chemistry, 51, 6941-6944.

41. Walker, M.D., \& Simpson, W.J. (1994). Control of sulphury flavours in cask conditioned beer. Brewers' Guardian, 123(11), 37-40. 